\title{
ІНФОРМАЦІЙНО-АНАЛІТИЧНЕ ЗАБЕЗПЕЧЕННЯ ІННОВАЦІЙНОГО РОЗВИТКУ ЕКОНОМІКИ УКРАЇНИ ЗА ЄВРОІНТЕГРАЦІЙНИХ УМОВ
}

\section{INFORMATION AND ANALYTICAL SUPPORT OF INNOVATIVE DEVELOPMENT OF UKRAINE'S ECONOMY UNDER EUROPEAN INTEGRATION CONDITIONS}

\author{
Завербний Андрій Степанович \\ доктор економічних наук, професор, \\ Національний університет «Львівська політехніка» \\ ORCID: https://orcid.org/0000-0001-7307-536X \\ Ноджак Любов Степанівна \\ кандидат економічних наук, доцент, \\ Національний університет «Львівська політехніка» \\ ORCID: https://orcid.org/ 0000-0002-8908-4241 \\ Міщанчук Софрія Анатоліївна \\ студентка, \\ Національний університет «Львівська політехніка» \\ ORCID: https://orcid.org/0000-0003-4185-7708
}

\author{
Zaverbnyj Andrij, Nodzhak Liubov, Mishchanchuk Sofiia \\ Lviv Polytechnic National University
}

\begin{abstract}
Стаття присвячена проблематиці інсрормаційно-аналітичного забезпечення інноваційного розвитку економіки України за євроінтеграційних умов. Проаналізовано динаміку фрінансування інноваційного діяльності в Україні протягом 2000-2020 років. Досліджено структуру науково-інсоормаційної діяльності та інсрормаційноаналітичної діяльності. Визначено сутність інфрормаційно-аналітичного забезпечення інноваційної діяльності. Встановлено, що система інформаційно-аналітичного забезпечення інноваційної сорери повинна фрормуватися інтегруванням інфрормаційних ресурсів (баз даних), що функціонують в Україні інформаційних, інфрормаційно-аналітичних систем супроводу інноваційної діяльності. Наведено перспективи гармонізування української системи статистичних індикаторів із європейськими. Визначено вагу малого і середнього бізнесу для активізування інноваційної діяльності.

Ключові слова: інфрормація, інфрормаційно-аналітичне забезпечення, інновації, інноваційний розвиток, євроінтегрування.
\end{abstract}

Статья посвящена проблематике информационно-аналитического обеспечения инновационного развития экономики Украины при евро интеграционных условиях. Проанализирована динамика фринансирования инновационной деятельности в Украине на протяжении 2000-2020 годов. Исследована структура научноинорормационной деятельности и информационно-аналитической деятельности. Определена сущность информационно-аналитического обеспечения инновационной деятельности. Установлено, что система инорормационно-аналитического обеспечения инновационной сферы должна фрормироваться интегрированием информационных ресурсов (баз данных), фрункционирующих в Украине инорормационных, инорормационноаналитических систем сопровождения инновационной деятельности. Приведены перспективы гармонизации украинской системы статистических индикаторов с европейскими. Определена роль малого и среднего бизнеса в активизации инновационной деятельности.

Ключевые слова: информация, информационно-аналитическое обеспечение, инновации, инновационное развитие, евроинтегрирование.

The article is devoted to the problems of information-analytical support of innovative development of Ukraine's economy under European integration conditions. The dynamics of financing of innovation activity in Ukraine during 
2000-2020 is analyzed. The structure of scientific and information activity and information and analytical activity is investigated. The essence of information-analytical support of innovation activity is determined. It is established that the system of information-analytical support of the innovation sphere should be formed by the integration of information resources (databases), functioning in Ukraine of information, information-analytical systems of support of innovation activity. Information and analytical support is actually a kind of scientific and information activity, which in the context of European integration, globalization of information and economic processes should be clearly focused on innovative development of Ukraine, commercialization of ideas, research results, products, and more. An essential problem of innovative development is a significant actual reduction in funding for this area in Ukraine. In order to develop the applied bases of information and analytical support of the innovation sphere, it is expedient to use a systematic approach. Prospects for harmonization of the Ukrainian system of statistical indicators with European ones are given. The importance of small and medium businesses for the intensification of innovative activity is determined. The need to ensure the availability of information on small and medium-sized companies in innovation reporting has been recognized. The system of information-analytical support of the innovation sphere should be formed by the integration of information resources, information, information-analytical systems of support of innovation activity with the prospect of integration into the European data, economic, innovation space. Among the promising areas of innovation development, the sphere should include research and coordination of processes of formation and implementation of innovative projects by domestic enterprises.

Keywords: information, information and analytical support, innovations, innovative development, European integration.

Постановка проблеми. Сучасні виклики євроінтегрування економіки України, її глобалізування, за умов високодинамічного світового технологічного прогресу і суттєве відставання України у модернізування власних виробничо-господарських потужностей, що загострюється фрінансово-економічною, політичною кризами, ескалацією військових дій з Росією, захопленням останньою території нашої країни вимагають фрормування ефрективної системи управління економікою, зокрема (і передусім) інноваційною сфрерою, як однією із перспективних для подальшого розвитку.

Аналіз останніх досліджень і публікацій. Проблематику інформаційно-аналітичного забезпечення інноваційної сорери досліджували такі науковці, як Амоша О.І. [1], Антонюк В.П. [1], Березняк Н.В. [2; 3], Вітковська К.В. [11], Височан О.С. [15], Геєць В.М. [4], Георгіаді Н.Г. [8], Голубєва Т.С. [5], Денисенко М.П. [5], Загородній А.Г. [15], Землянкін А.І. [1], Ілляшенко С.М. [6], Кваша Т.К. [2], Квак С.А. [7], Колос І.В. [5], Кравець А.І. [10], Кузьмін О.Є. [8], Леховіцер В.О. [9], Манаєнко І.М. [10], Ольвінська Ю.О. [11], Поліщук О.О. [13], Самотоєнкова О.В. [11], Фатхутдінов Р.А. [14], Шквір В.Д. [15], а також багато інших.

Виділення невирішених раніше частин загальної проблеми. Одночасно певні теоретико-методологічні аспекти інфрормаційноаналітичного забезпечення інноваційної сорери потребують додаткового дослідження із урахуванням високого рівня динаміки, перспектив, які виникають за умов євроінтегрування економіки України.
Формулювання цілей статті (постановка завдання). Основними завданнями $€$ дослідження перспектив розвитку інфоормаційноаналітичного забезпечення інноваційного розвитку економіки України, організування гармонійного потоку високоесрективних нововведень, активного переходу вітчизняної економіки на застосування наукоємних технологій враховуючи позитивні умови євроінтеграції.

Виклад основного матеріалу дослідження. Інфрормаційно-аналітичне забезпечення - це «система одержання, оцінювання, оброблення, зберігання, передавання інформації, що створена задля розроблення ефективних управлінських рішень на всіх рівнях системи управління» [1; 3]. Інфрормаційноаналітичне забезпечення власне $є$ різновидом науково-інорормаційної діяльності, що за умов євроінтегрування, глобалізування інфрормаційно-економічних процесів має чітко зорієнтовуватися на інноваційний розвиток України, комерціалізування ідей, результатів наукових досліджень, розробок тощо. Актуальним $\epsilon$ розроблення стратегії, тактики переходу від процесів пасивного акумулювання інорормації науково-технічної, інноваційної сфер до трансформування їх до цілісної, чітко зорієнтованої на потенційних користувачів високо ефрективну систему знань. Для цього рефрормування потрібно передусім поглиблено дослідити методологічні, практичні основи інсрормаційно-аналітичного забезпечення інноваційної сорери [1; 3], провідний європейський досвід.

Ключовим різновидом науково-інсрормаційної діяльності виступає інформаційно-аналітична діяльність. Вона повинна виконувати 
завдання із якісно-змістовного трансформування первинної інфрормації, за умов функціонального перетину із науковою (продукування нових знань) і управлінською (розроблення альтернативних варіантів вирішення, сценаріїв тощо) діяльністю [3].

Інформаційний підхід до інфрормаційноаналітичної діяльності дозволятиме відносити її до напрямку інформаційної діяльності, аналітичний підхід дозволятиме трактувати інформаційно-аналітичну діяльність в якості творчої, призначеної для оцінювання інфрормації, підготовлення до прийняття управлінських рішень [3].

Універсальний алгоритм інформаційноаналітичної діяльності був створений ще В. Плеттом (американським генералом) [1; 3]. Адже досить багато термінів власне мають військове коріння («стратегія», «тактика», «структура» тощо). На думку Плетта В., даний процес повинен складатися із 7 базових етапів: загальне ознайомлення із проблематикою, встановлення (визначення) понять (тер- мінів), що використовуватимуться, збирання інформації (фрактів), їх тлумачення, фрормування гіпотези, фрормулювання висновків; офрормлення результативного аналітичного матеріалу [1; 2; 3].

Важливою проблемою інноваційного розвитку є суттєве реальне скорочення фрінансування даної сфрери в Україні. Якщо номінальне фрінансування (рис. 1) маю позитивний тренд, то реальне фрінансування (із врахуванням падінням у 2014 р. курсу національної валюти у відношенню до конвертованих світових валют більш ніж втричі) суттєво скоротилося. Винятком був лишень 2016 р., де спостерігається суттєвий приріст, але вийти на рівень 2007-2013 рр. поки що так і не вдалося (див. рис. 1) [12].

Саме тому для оптимізування фрінансування інноваційної сорери доцільним $є$ удосконалення інфрормаційно-аналітичного забезпечення економічного, правового механізмів мотивування активізування інноваційної діяльності, покращення інвестиційного

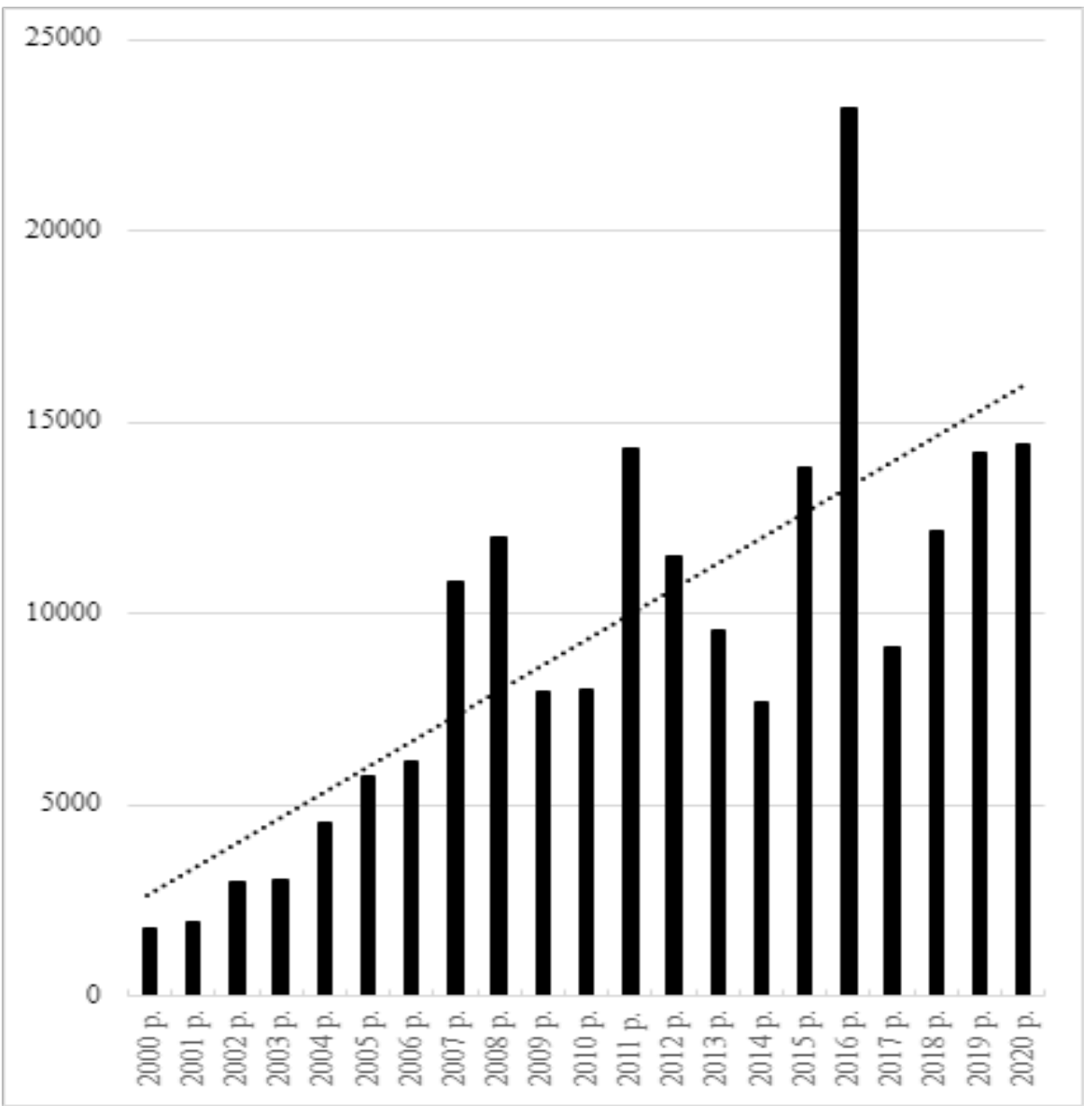

Рис. 1. Динаміка обсягів сукупних витрат на інновації в Україні протягом 2000-2020 рр., млн. грн.

Джерело: [12] 
клімату (в т. ч. й для залучення іноземних капіталів в інноваційну ссреру).

Задля розвитку прикладних основ інорормаційно-аналітичного забезпечення інноваційної сорери доцільно застосовувати системний підхід [1; 3] при фрормуванні пропозицій зі створення інорормаційного механізму (системи) задовольняючи потреби інноваційноактивної економіки.

Такий механізм повинен передбачати організування стабільного інфрормаційного потоку високоесективних нововведень (інновацій) та перехід економіки України на застосування наукомістких технологій [6], а не залишатися сировинним придатком для розвинених країн.

Система інформаційно-аналітичного забезпечення інноваційної ссрери має фрормуватися інтегруванням інфрормаційних ресурсів (баз даних), що фрункціонують в Україні інсрормаційних, інорормаційно-аналітичних систем супроводу інноваційної діяльності (на трьох рівнях: загальнодержавному, регіональному, галузевому) із перспективою інтегрування до європейського інфрормаційного, економічного, інноваційного простору.

Формуючи систему інформаційно-аналітичного забезпечення інноваційної ссрери України необхідно враховувати, що інсрормаційне забезпечення інноваційного процесу повинне містити наступні елементи $[1 ; 3 ; 7 ; 8$; 13; 14]: безпосередньо інфрормацію (інфрормаційні масиви), що $є$ інформаційно-ресурсною складовою системи, інституції, що здійснюватимуть пошук, збирання (акумулювання), оброблення (аналізування), зберігання, передавання, поширення інфрормації, що виступає інституційною складовою системи, канали передавання інформації (інформаційні технології, засоби зв'язку, комунікування, інсрормаційні мережі та ін.), що становить інфрормаційно-комунікаційну складову вказаної системи.

Зазначена система сприятиме фрормуванню ефективної системи управління інфрормаційними ресурсами інноваційної сорери [1; 3; 7]: вирішенню проблеми, що є пов'язаними із потребами удосконалення вітчизняної законодавчої, нормативно-правової бази із питань науково-технічної, інноваційної діяльностей; розробленням держстандартів у інноваційній сорері, гармонізування їх зі стандартами ISO, для забезпечення їх сумісності, інтегрованості; запровадженням моніторингу інфроресурсів (для налагодження ефективного інфрормаційного обміну, уникнення дублювання при формуванні баз даних), управлінням вітчизняними інсормаційними ресурсами вказаної сфрери, формуванням інфрраструктури задля розбудови і подальшого розвитку інтелектуального інформаційного простору в країні тощо.

Зокрема також доцільним для фрормування ефрективної, прозорої інформаційно-аналітичної системи при фрормуванні інноваційної політики України потрібно вирішити наступні завдання [7]:

1) гармонізування системи індикаторів із європейськими (Європейським інноваційним табло (ЄIT), індикаторами досягнення цілей гармонійного розвитку), адаптування до них. У країнах $Є С$ основу (базис) інсрормаційно-аналітичного забезпечення інноваційної діяльності фрормує саме ЄIT, яке забезпечує порівняльне оцінювання досліджень, інноваційної діяльності країн ЄС, сильних/ слабких сторін інноваційної системи, що допомагає оцінювати сорери, в яких країни $€ C$ повинні сконцентрувати зусилля задля підвищення рівнів ефективності їх інноваційної діяльності. Вказана система вимірювань Європейського інноваційного табло розрізняє 4 види критеріїв (умови інноваційної діяльності, процеси інвестування та безпосередньо інноваційної діяльності, вплив інноваційної діяльність на розвиток економіки (зокрема, рівень зайнятості, доходності від впровадження інновацій тощо) і 10 інноваційних вимірів, охоплюючих аж 27 індикаторів;

2) забезпечення наявності у звітності із інноваційної діяльності інформації про малий і середній бізнес (як це відбувається в $€$, де виокремлено кілька індикаторів у ЄIT);

3) використання аналітичних індикаторів, які даватимуть змогу обґрунтовувати пріоритетні напрямки для інноваційного розвитку, оцінювати відповідні ефекти;

4) удосконалення методологій облікування інноваційної діяльності із застосуванням допоміжного сателітного рахунку [7] тощо.

Висновки. До перспективних напрямків розвитку інноваційної сорери доцільно віднести дослідження і координування процесів формування і реалізування інноваційних проєктів вітчизняними підприємствами, подальше вдосконалення структури та інфрормаційної наповненості державної інноваційної політики нашої країни, пошук дієвих механізмів інорормаційної підтримки та стимулювання забезпеченості фрінансовими ресурсами (пільги (в оподаткуванні, в наданні кредитів та ін.), дотування інноваційної ссрери тощо) інноваційної діяльності. 


\section{СПИСОК ВИКОРИСТАНИХ ДЖЕРЕЛ:}

1. Амоша О.І., Антонюк В.П., Землянкін А.І. Активізація інноваційної діяльності: організаційно-правове та соціально-економічне забезпечення. Донецьк, 2007. 328 с.

2. Березняк Н.В., Кваша Т.К. Дослідження теоретичних і практичних основ інфоормаційно-аналітичного забезпечення науково-технічної та інноваційної діяльності : Наукова доповідь. Київ : УкрIHTEI, 2017. 72 с.

3. Березняк Н.В. Проблеми інфрормаційно-аналітичного забезпечення інноваційної діяльності. Наука, технології, інновації. 2018. № 1. С. 37-42.

4. Геєць В.М. Інституційна обумовленість інноваційних процесів у промисловому розвитку України. Економіка України. 2014. № 12. С. 4-19.

5. Денисенко М.П., Голубєва Т.С., Колос І.В. Інформаційне забезпечення інноваційно-інвестиційної діяльності підприємства. Вісник НУ «Львівська політехніка». 2009. № 647. С. 43-49.

6. Ілляшенко С.М. Маркетинг. Менеджмент. Інновації : монографрія. Суми : ТОВ «Друкарський дім «Папірус», 2010. $623 \mathrm{C}$.

7. Квак С.А. Економічний механізм стимулювання інноваційної діяльності промислових підприємств України : дис. .... канд. екон. наук : 08.00.03. Львів, 2020. 289 с.

8. Кузьмін О.Є., Георгіаді Н.Г. Формування і використання інформаційної системи управління економічним розвитком підприємства : монограсія. Львів : В-во Національного університету «Львівська політехніка», 2006. 368 с.

9. Леховіцер В.О. Методичні основи оцінки впливу факторів на інноваційний розвиток машинобудування. Науковий вісник Херсонського державного університету. 2017. Випуск 25. Частина 1. С. 156-158.

10. Манаєнко І.М., Кравець А.І. Фінансування інноваційної діяльності підприємств: українські реалії та досвід ЄС. Економіка та управління підприємствами. 2018. № 5. С. 109-115.

11. Ольвінська Ю.О., Самотоєнкова О.В., Вітковська К.В. Сучасний стан та тенденції розвитку інноваційної діяльності в Україні. Економіка та держава. 2021. № 4. С. 64-71.

12. Офіційний сайт Державної служби статистики України. URL: http://www.ukrstat.gov.ua/ (дата звернення: 31.10.2021).

13. Поліщук О.О. Сутність поняття «інноваційна діяльність» як соціально-економічної категорії. Економічний вісник Донбасу. 2018. № 3(21). С. 169-171.

14. Фатхутдинов Р.А. Инновационный менеджмент. Санкт Петербург : Питер-пресс, 2008. 442 с.

15. Шквір В.Д., Загородній А.Г., Височан О.С. Інформаційні системи і технології в обліку : навчальний посібник. Львів : В-во Національного університету «Львівська політехніка», 2003. 268 с.

\section{REFERENCES:}

1. Amosha A.I., Fedorenko V.G., Belopolskii N.G., Turchenko D.K. (2007) Ekonmicheskie podhody k efektivnomu ispolzovaniu energrticheskikh resursov [Economic approaches to the efficient use of energy resources]. Ekonomika ta derzava, 1, 4-7. (in Russian)

2. Berezniak N.V., Kvasha T.K. (2017) Doslidzhennia teoretychnykh i praktychnykh osnov incpfrmacijno-analitychnogo zabezpechennia naukovo-tekhnichnoi ta innovacijnoi dijalnosti [Research of theoretical and practical bases of information-analytical support of scientific-technical and innovative activity]: Naukova dopovid. Kyiv: UkrINTEl, $72 \mathrm{p}$.

3. Berezniak N.V. (2018) Problemy informacijno-analitychnogo zabezpechennia innovacijnoi dijalnosti [Problems of information and analytical support of innovation]. Nauka, tekhnologii, innovacii, 1, 37-42.

4. Geyec V.M. (2014) Instytucijna obumovlenist innovacijnykh procesiv u promyslovomu rozvytku Ukrainy [Institutional conditionality of innovation processes in the industrial development of Ukraine]. Ekonomika Ukrainy, 12, 4-19. (in Ukrainian)

5. Denysenko M.P., Holubieva T.S., Kolos I.V. (2009) Informatsiine zabezpechennia innovatsiino-investytsiinoi diialnosti pidpryiemstva [Information support of innovation and investment activities of the enterprise]. Lvivska politekhnika (electronic journal), vol. 11, no. 115, pp. 43-49. (in Ukrainian)

6. Illiashenko S.M. (2010) Marketyng. Menedzment. Innovacii: monogrfia [Marketing. Management. Innovations: monograph]. Sumy: TOV «Drukarsky dim «Papirus», $623 \mathrm{p}$.

7. Kvak S.A. (2020) Ekonomichnyi mekhanizm stymuliuvannia innovacijnoi diyalnosti promyslovykh pidpryiemstv Ukrainy [Economic mechanism of stimulation of innovative activity of industrial enterprises of Ukraine]. Candidate's thesis. Lviv. (in Ukrainian)

8. Kuzmin O.Ye., Heorhiadi N.H. (2006) Formuvannia i vykorystannia informatsiinoi systemy upravlinnia ekonomichnym rozvytkom pidpryiemstva: monohrafiia [Formation and use of information management system of economic development of the enterprise: monograph]. Lviv: Vyd-vo Nats. un-tu "Lvivska politekhnika". (in Ukrainian) 
9. Lekhovicer V.O. (2017) Metodychni osnovy ocinky vplyvu faktoriv na innovacijnyj rozvytok mashynobuduvannia [Methodical bases of estimation of influence of factors on innovative development of mechanical engineering]. Naukovyj visnyk Khersonskogo derzavnogo universytetu, 25(1), 156-158. (in Ukrainian)

10. Manayenko I.M., Kravec A.I. (2018) Finansuvannia innovacijnoi diyalnosti pidpryjemstv: ukrainski realii ta dosvid ES [Financing of innovative activity of enterprises: Ukrainian realities and experience of the EU]. Ekonomika ta upravlinnia pidpryjemstvamy, 5, 109-115. (in Ukrainian)

11. Olvinska Yu.O., Samotoyenkova O.V., Vitkovska K.V. (2021) Suchazny stan ta tendencii rozvytku innovacijnoi diyalnosti v Ukraini [Current state and trends in the development of innovation in Ukraine]. Ekonomika ta derzhava, 4, 64-71. (in Ukrainian)

12. Oficijnyi sajt Derzavnoi sluzby statystyky Ukrainy [Official site of the State Statistics Service of Ukraine]. Available at: http://www.ukrstat.gov.ua/ (accessed 31 October 2021). (in Ukrainian)

13. Polishchuk O.O. (2018) Sutnist poniattia "innovatsiina diialnist" yak sotsialno-ekonomichnoi katehorii [The essence of the concept of "innovation" as a socioeconomic category]. Ekonomichnyi visnyk Donbasu, vol. 3 , no. 21, pp. 169-171. (in Ukrainian)

14. Shkvir V.D., Zahorodnii A.H., Vysochan O.S. (2003) Informatsiini systemy i tekhnolohii v obliku: navch. posibnyk [Information systems and technologies in accounting: textbook]. Lviv: Vydavnytstvo Natsionalnoho universytetu "Lvivska politekhnika". (in Ukrainian)

15. Fatkhutdinov R.A. (2008) Innovatsionnyy menedzhment [Innovation Management]. St. Petersburg: Piterpress. (in Russian) 